\title{
ASPECTOS DO ENSINO DO DIREITO ROMANO NA FACULDADE dE DIREITO DE SÃo PAULO, DURANTE O IMPÉRIO
}

\author{
José Carlos Moreira Alves* \\ Professor Catedrático da Faculdade de Direito da USP
}

Sumário:

1. O ensino do Direito Romano no Projeto de Estatutos organizado pelo Visconde da Cachoeira.

2. A introdução da disciplina no currículo dos cursos jurídicos.

3. Os professores de Direito Romano na Faculdade de Direito de São Paulo, de 1854 a 1889.

4. Os compêndios empregados no ensino do Direito Romano.

5. O método de seu ensino.

6. O método sintético-compendiário e a produção de obras didáticas pelos professores de Direito Romano na Faculdade de São Paulo.

1. O ENSINO DO DIREITO ROMANO NO PROJETO DE ESTATUTOS ORGANIZADO PELO VISCONDE DA CACHOEIRA:

Depois da tentativa frustrada da criação de cursos jurídicos pela Assembléia Constituinte de 1823, criou-se, por Decreto de 9 de janeiro de 1825, firmado pelo Marquês de Valença, então Ministro do Império, um curso jurídico provisório na Corte, o qual, no entanto, não chegou a instalar-se. Sua criação, porém, deu origem a Projeto de Regulamento ou de Estatutos redigido pelo Visconde da Cachoeira, Luís José de Carvalho e Melo.

Já por ocasião dos debates na Assembléia Constituinte, Carvalho e Melo apoiara os autores do projeto de lei da criação, no Brasil, de duas universidades, inclusive quanto à adoção provisória, para reger um curso jurídico em São Paulo que desde logo se implantaria, dos Estatutos da Universidade de Coimbra, com as alterações que se fizessem necessárias. Dissera, então, em

* Ministro do Supremo Tribunal Federal. 
discurso proferido na sessão de 27 de agosto de 1823 :

"Mui acertado é, que assim se execute, e sou de parecer que os reféridos mestres têm mais que cortar de tais Estatutos, do que inovar e acrescentar. Foram seus autores muito sábios, e mais há que notar neles de sobejo de enudição e doutrina do que em míngua de cabedal. Pasmoso foi, por certo, que na época de tal instituiçāo em que Portugal carecia de todas as luzes, digamo-lo sem vergonha, maiormente de conhecimentos filosófico-jurídicos, de Direito Público Universal e Eclesiástico, e das Gentes, e de quase todas as ciências naturais, aparecessem homens dotados de tanto saber, que apresentassem tais Estatutos dignos por certo dos maiores elogios". 1

No Projeto de Estatutos que posteriormente redigiu - é ele datado de 2 de março de 1825 , Carvalho e Melo justificou a necessidade de sua elaboração para os cursos jurídicos porque, embora não se pudesse negar a sabedoria dos autores dos Estatutos da Universidade de Coimbra,

"... o seu nímio saber em Jurisprudência, e
demasiada erudição de que sobrecarregaram os
mesmos Estatutos, a muita profusāo de Direito
Romano de que fizeram a principal ciência juridica, a
exemplo das Universidades da Alemanha; o muito
pouco que mandaram ensinar da Jurisprudência pátria,
amontoando só em um ano, e em uma só cadeira de
Direito Natural, Público, e das Gentes (sem se lhe unir
a parte diplomática) e que devia ser ensinada em um só
ano; a falta de Direito Marítimo, Comercial, Criminal, e
de Economia Política, que não foram compreendidas
nos estudos, que se deviam ensinar dentro do
qüinqüênio, fazem ver que os referidos Estatutos, tais
como se acham escritos, não podem quadrar ao fim
proposto de se formarem por eles verdadeiros e hábeis
jurisconsultos" 2

1. Criação dos Cursos Jurídicos no Brasil, Documentos Parlamentares, Brasília, 1977, v. 122, p.

2. Ibid., p. 589. 
Pelo Projeto do Visconde da Cachoeira, os estudantes que pretendessem matricular-se no curso jurídico deveriam ser aprovados em exames preparatórios, em que uma das disciplinas era a língua latina, cujo conhecimento era indispensável, não só por estarem escritos nela o Digesto, o Código, as Novelas, as Institutas e os bons livros de Direito Romano, mas também as Instituições de Melo Freire e as obras jurídicas de escritores de nota. Institutas do Direito Romano era a cadeira em que este devia ser estudado, e estava incorporada no primeiro ano, ao lado da de Direito Natural e Público Universal. $\mathrm{O}$ escopo do ensino dessa disciplina era a sua aplicação à prática do foro. Por isso, o professor, depois de expor-lhe resumidamente a história pelas suas diversas épocas, e de dar uma notícia das Institutas, do Digesto, do Código e das Novelas, deveria explicar que ele, entre nós, nunca tivera autoridade extrínseca, mas fora sempre subsidiário, e estudar as suas doutrinas gerais, para que o aluno viesse a conhecer o que dele merecia aplicação por se fundar no Direito Natural e o que nele devia ser reprovado por não ter tal base. Como instrumento de ensino, uma vez que as Institutas de Justiniano não se prestavam para fazer essa distinção, deveria ser adotado o compêndio de Waldeck, que resumira aquelas Institutas, afastando o que já não devia ser estudado, e isso se faria até que o professor redigisse novo compêndio em que observaria método semelhante, salientando, no fim de cada parágrafo ou capítulo, as doutrinas que eram, ou não, reprovadas pelo Direito brasileiro, à semelhança do que fizera Heinécio em seu compêndio das Pandectas. Com esse conhecimento das instituições mais gerais do Direito Romano, estaria o aluno apto a receber, nos terceiro e quarto anos, ensinamentos mais específicos, nas cadeiras de Direito pátrio, sobre as origens romanas de institutos de Direito Civil, bem como sobre o uso moderno do Direito Romano como direito subsidiário na prática forense.

Por não ter sido instalado - como já se acentuou - o curso jurídico para o qual foi redigido esse Projeto de Estatutos, teria ficado ele sem utilização se a lei de 11 de agosto de 1827, que criou os Cursos de Ciências Jurídicas e Sociais em São Paulo e em Olinda, não houvesse disposto em seu artigo 10:

"Os Estatutos do Visconde da Cachoeira ficarão regulando por ora naquilo em que forem aplicáveis; e se não opuserem à presente Lei. A Congregação dos Lentes formará quanto antes uns estatutos completos, 
que serão submetidos à deliberação da Assembléia
Geral"

Na parte concernente à cadeira de Direito Romano, porém, ficava ele sem aplicação, pois essa Lei não incluíra as Institutas de Direito Romano no currículo dos cursos que criara.

\section{A INTRODUÇÃO DA DISCIPLINA NO CURRÍCULO DOS CURSOS JURÍDICOS.}

O Direito Romano não foi incluído no currículo dos cursos jurídicos de São Paulo e de Olinda criados pela lei de 11 de agosto de 1827 depois de acirrada discussão na Câmara dos Deputados e no Senado. Essa controvérsia, aliás, já se verificara no debate, na Assembléia Constituinte, sobre a "indicação" com que, em 14 de junho de 1823, José Feliciano Fernandes Pinheiro propunha que se criasse, no Brasil, uma universidade. E seus reflexos se fizeram sentir no Projeto de Estatutos do Visconde da Cachoeira que reduziu o ensino do Direito Romano a uma cadeira voltada à sua aplicação prática como direito subsidiário.Os ataques ao estudo do Direito Romano nos cursos jurídicos que se criavam decorreram, basicamente, da ênfase dada a ele, em detrimento do direito pátrio, em Coimbra, onde vários deputados e senadores haviam estudado. A demasia, ao invés de levar à redução, conduziu à supressão. $\mathrm{O}$ exagero do resultado encontra explicação na antipatia, que ressalta nítida dos debates parlamentares, àquela disciplina resultante da forma como era estudada na Universidade portuguesa. Aqui e ali, encontram-se recordações sugestivas, como a de Batista Pereira: "por desgraça minha, fui forçado a estudar quatro anos esse informe código de contradições, ficções, e barbaridades, e são poucas as lágrimas que derramo, quando me recordo que, depois de tantas vigilias, aprendi uma legislação que pequeno préstimo me podia dar ainda no sistema absoluto, pois que a Lei de 18 de agosto de 1769 me ordena que o siga, só quando as suas disposiçōes se conformarem com a boa razão; ora, Sr. Presidente, tanto estudo para afinal seguir os ditames do meu bom senso é mais que puerilidade". 3

3. Criação dos Cursos... ob. cit., p. 281. 
Que as lembranças de Coimbra, quanto à eficiência de seu ensino, não eram boas, dão prova disso estas críticas do deputado Vasconcelos, ao sustentar que o curso jurídico deveria instalar-se no Rio de Janeiro e não nas províncias:

"Queria que me dissessem estes senhores, que gostam das ciências do sertão, se há nessas províncias pessoas que possam constituir a censura pública, tão necessária para o bom andamento e progresso dos estabelecimentos literários. Eu as não conheço. Pois sem essa censura não se apuram os conhecimentos; porque, como o ordenado vai correndo e contam-se os anos para a jubilação, quer se ensine bem, quer mal, quer se tenha merecimento, quer não, os mestres entregam-se inteiramente ao ócio e os alunos fazem o mesmo, à espera que se encha o tempo para obterem as cartas, pois é bem sabido que, quando o mestre dorme, os meninos brincam. Isto é justamente o que acontecia na Universidade de Coimbra no meu tempo; nenhuma emulação, nenhum estímulo se notava ali e por isso nenhum progresso nas letras.

Ninguém se deve dar por escandalizado nesta verdade; e para isso eu falarei do que passou por mim próprio, pois tenho franqueza para isso.

Estudei Direito Público naquela Universidade e por fim saí um bárbaro: foi-me preciso até desaprender. Ensinaram-me que o Reino de Portugal e acessórios era patrimonial; umas vezes sustentavam que os portugueses foram dados em dote ao senhor D. Afonso I, como se dão escravos ou lotes de bestas, outras vezes diziam que Deus, no campo de Ourique, lhe dera todos os poderes e à sua descendência; umas vezes negava-se a existência das Cortes de Lamego, outras confessava-se a existência, mas negava-se a soberania que os povos nelas exerceram; dizia-se que aquela $e$ as outras assembléias da Nação Portuguesa apenas tiveram de direito $e$ de fato um voto consultivo: o direito de resistência, esse baluarte da liberdade, era inteiramente proscrito; e desgraçado de quem dele se lembrasse! Estas e outras doutrinas se ensinam naquela Universidade, e por quê? Porque está inteiramente incomunicável com o resto do mundo científico. 
Ali não se admitem correspondência com outras academias; ali não se conferem os graus, senão àqueles que estudaram o ranço dos seus compêndios; ali estava alerta continuadamente uma Inquisição, pronta a mandar às chamas todo aquele que tivesse a desgraça de conhecer qualquer verdade, ou na religião, ou na Jurisprudência, ou na política.

Daí vinha que o estudante, que saía da Universidade de Coimbra, devia, antes de tudo, desaprender o que lá se ensinava e abrir nova carreira de estudos" 4

Durante vinte e seis anos de 1828 a 1854 - os dois únicos cursos jurídicos existentes no Brasil funcionaram sem a cadeira de Direito Romano. Sua necessidade, porém, até para o estudo mais completo de nosso Direito Civil, acabou por impor sua admissão no currículo. O Decreto Legislativo de 16 de agosto de 1851 incluiu, no segundo ano, a cadeira de Institutos de Direito Romano, a qual só foi instalada três anos mais tarde, em 1854. Em São Paulo, essa instalação se deu em setembro desse ano. Já estavam em vigor, em substituição aos do Visconde da Cachoeira, os Estatutos dos cursos jurídicos mandados observar pelo Decreto 1.386, de 28 de abril de 1854. Por eles (art. $1^{9}$ ), "os atuais cursos jurídicos serão constituídos em Faculdades de Direito; designando-se cada uma pelo nome da Cidade, em que tem, ou possa ter assento". No ano seguinte, era aprovado pelo Decreto 1.568 , de 24 de fevereiro, o Regulamento complementar dos Estatutos das Faculdades de Direito, expedido na conformidade do $\S 3$ o do art. 21 do citado Decreto 1.386 .

\section{OS PROFESSORES DE DIREITO ROMANO NA FACULDADE DE SÃO} PAULO, DE 1854 A 1889.

Quatro foram, sucessivamente, os professores catedráticos de Direito Romano que a Faculdade de São Paulo teve durante o Império: João Crispiniano Soares, Manuel Antônio Duarte de Azevedo, Francisco Antônio Dutra Rodrigues e Américo Brasiliense de Almeida Melo.

João Crispiniano Soares, nascido em 24 de junho de 1809, na Freguesia da Conceição de Guarulhos (SP), aprendeu latim na aula régia do

4. Criação dos Cursos... ob. cit., p. 233-235. 
Professor André da Silva Gomes, e, em 1830, quando ainda não se ensinava Direito Romano na Faculdade de São Paulo - que, no entanto, exigia para o ingresso nela a aprovação em gramática latina matriculou-se no curso jurídico, vindo a receber o diploma de bacharel em dezembro de 1834. Doutorou-se em 1835. Em 23 de abril de 1836, foi nomeado lente substituto. Fez carreira política, tendo sido deputado provincial e geral, e Presidente das Províncias de Mato Grosso, Minas Gerais, Rio de Janeiro e São Paulo. Por Decreto de 8 de julho de 1854, foi nomeado professor catedrático de Direito Romano, e, no ensino dessa disciplina, ganhou renome no país. O discurso inaugural, que proferiu em 1854, nessa cadeira, então introduzida nos cursos jurídicos, teve larga repercussão, havendo sido considerado monumento de erudição e de eloqüência. Nas suas lições, professava as doutrinas da Escola Histórica germânica, e seu autor preferido era Savigny. Graças a isso como se verá no próximo item deste trabalho substituiu o compêndio de Waldeck pelo de Warnkoenig como base de suas lições. Muito orgulhoso, começava suas aulas em voz baixa e a ía elevando na medida em que desenvolvia o tema, e com freqüência dizia que Papiniano, Cujácio e outros haviam errado ao sustentar certas opiniōes. Sacramento Blake ${ }^{5}$ dá notícia de um Tratado sobre Fontes do Direito Pátrio escrito por Crispiniano em colaboração com seu colega e amigo Joaquim Ignácio Ramalho, catedrático de Direito Processual Civil; não se conhece, porém, qualquer exemplar dessa obra. Embora Duarte de Azevedo que, mais tarde, o substituiu na cátedra de Direito Romano tenha alcançado um compêndio escrito por Crispiniano para uso de seus alunos, e que seria resumido, claro, metódico e seguro nas suas doutrinas, o certo é que não foi ele impresso, e não se conhece dele nenhuma

5. Dicionário Bibliográfico Brasileiro, Rio de Janeiro, Imprensa Nacional, 1895, v. 3, p. 396 (reimpressão de off-set feita pelo Conselho Federal de Cultura, Rio de Janeiro, 1970). 
cópia. ${ }^{6}$ João Crispiniano Soares jubilou-se como professor, em 21 de agosto de $1871 .^{7}$

Para preencher a vaga deixada por Crispiniano, foi nomeado lente catedrático de Direito Romano, em 15 de novembro de 1871, Manoel Antônio Duarte de Azevedo. ${ }^{8}$ Nascido em Itaboraí, na Província do Rio de Janeiro, em 16 de janeiro de 1832, ingressou na Faculdade de Direito em 1852, bacharelandose em 1856. Em 4 de agosto de 1859, recebeu o grau de doutor em Direito. Na política, ocupou o cargo de Presidente das Províncias do Piauí (em 1860), de Alagoas (em 1861) e do Ceará (em 1862). Em decorrência de concurso, foi nomeado professor substituto em 9 de agosto de 1862, e como tal permaneceu até sua nomeação como catedrático de Direito Romano, em substituição a Crispiniano. Deixou grande fama no exercício do magistério. Dizendo-o tipo perfeito de professor, assim sintetizou Spencer Vampré suas qualidades para o ensino: "a precisão, o método, a clareza, a simplicidade expositiva, a profundidade dos conceitos, a elegância da forma, e uma irradiante simpatia". 9

Pelágio Lôbo, cujo pai foi aluno de Duarte de Azevedo em 1880, assim se refere a este: "O velho Duarte, conselheiro do Império, era um grande professor: - fluente, claro, seguro, sem arroubos, ensinava o Direito Romano percorrendo, numa série de aulas pontualíssimas, todo o programa, no que este apresentava de essencial e básico. Suas lições, claras, desembaraçadas, dadas à classe numa exposição de invejável fluência, sem arrebiques desnecessários e sem rasgos de eloqüência, ensinavam, de verdade, a matéria e habilitavam a classe a

6. Sobre esse compêndio, informa Almeida Nogueira: "Temos notícia, igualmente, de um compêndio de Direito Romano, da lavra do eminente romanista, para curriculum dos seus discípulos. Também ficou inédito. Este trabalho esteve, por empréstimo do seu preclaro autor, em mãos do conselheiro Duarte de Azevedo, que nele admirou o método, a clareza e a segurança das doutrinas, não obstante ser obra resumida, um manual, mais que um expositor" (Tradiçóes $e$ Reminiscências da Academia de São Paulo, São Paulo, A Editora, 1909, v. 6, p. 73.

7. A respeito dos dados biográficos de Crispiniano, vide Azevedo Marques, Apontamentos Históricos, Geográficos, Biográficos, Estatísticos e Noticiosos da Província de São Paulo, Sa. edição, Belo Horizonte, Itatiaia/EDUSP, 1980, t. 2, p. 34-35; Sacramento Blake, ob. cit., 1895, v. 3, p. 396; Almeida Nogueira, ob. cit., v. 6, p. 68-78; e Spencer Vampré, Memórias para a História da Academia de São Paulo, $2^{\mathrm{a}}$ edição, Brasília, Instituto Nacional do Livro e Conselho Federal de Cultura, 1977, v. 1, p. 180-184.

8. Para a biografia de Duarte de Azevedo, vide Sacramento Blake, ob. cit., v. 6, p. 16-18; e Spencer Vampré, ob. cit., v. 2, p. 123-126.

9. Ob. cit., v. 2, p. 124 . 
guardar uma noção suficiente desse Direito, de forma a assegurar-lhe o indispensável desenvolvimento futuro". ${ }^{10}$ Advogado de grande renome, foi eleito deputado várias vezes à Assembléia Provincial e à Assembléia Geral; participante do Gabinete de 7 de março de 1871, foi nele, de início, Ministro da Marinha, e, depois, Ministro da Justiça. Jubilou-se na Faculdade, em 28 de maio de 1881. É de notar-se que, ainda quando lente substituto, Duarte de Azevedo, na Memória Histórica da Faculdade, relativa ao ano de 1864, já criticava o currículo dos cursos jurídicos, assim aludindo ao Direito Romano: "O Direito Romano, a mais próxima e abundante fonte de nosso direito privado, a base de todas as legislações civis dos povos da Europa, como disse Cousin, a mais bela aplicação da lei natural, na frase de Bossuet, a razão escrita, e o direito modelo, como a denominaram tantos outros, ai é ensinado em um ano só: e, o que é mais grave, ensinado no primeiro ano da Faculdade, quando a inteligência dos alunos, removida de chofre dos estudos preparatórios para as aulas de Direito, não está ainda em estado de investir com as dificuldades da mais técnica e sistemática das legislações conhecidas". ${ }^{11} \mathrm{E}$, na reorganização que propunha para as Faculdades de Direito (que daria dois cursos, um de ciências sociais em dois anos e outro de ciências jurídicas em quatro anos); incluía, no curso de ciências jurídicas, duas cadeiras de Direito Romano: uma no segundo ano e outra no terceiro. ${ }^{12}$

A Duarte de Azevedo segue-se, na cátedra de Direito Romano, Francisco Antônio Dutra Rodrigues. ${ }^{13}$ Carioca, bacharelou-se em São Paulo em 1865, tendo recebido o grau de doutor em Direito em 1866. Classificado em primeiro lugar no concurso para professor substituto, foi nomeado a 9 de outubro de 1872. Ascendeu à cátedra de Direito Romano por Decreto de 25 de junho de 1881, e a deixou em virtude do falecimento ocorrido em 29 de setembro de 1888. Sua atuação como professor é assim referida por Spencer Vampré:

"Foi Dutra Rodrigues afamado professor: - embora prolixo, e difuso, era penetrante nas críticas, e as suas

10. Recordações das Arcadas, São Paulo, Reitoria da Universidade de São Paulo, 1953, p. 270.

11. Apud Spencer Vampré, ob. cit., v. 2, p. 137.

12. Ibidem.

13. A respeito de sua biografia, vide Sacramento Blake, ob. cit., 1893, v. 2, p. 393-394; e Spencer Vampré, ob. cit., v. 2, p. 224. 
apostilas de Direito Romano, conhecidas pelos nomes de Dutrinha, e Dutrão, serviram de pábulo a muitas gerações de estudantes.

Falava torrencialmente, como José Bonifácio, mas repetia, em cada ano, quase literalmente, o que expusera nos anteriores.

Quando freqüentamos a Faculdade, no qüinqüênio de 1905 a 1909, eram ainda lidas as suas lições, com justo acatamento" 14

O último catedrático de Direito Romano nomeado antes da queda do Império, ocorrida em 1889, foi Américo Brasiliense de Almeida Melo. Nascido em São Paulo, em 8 de agosto de 1833, matriculou-se na Faculdade de Direito em 1851, bacharelando-se em 1855. Doutorou-se em 1860. Advogado e político, foi nomeado professor substituto em 11 de setembro de 1882, depois de classificar-se em primeiro lugar no respectivo concurso. Em 3 de outubro de 1888 foi promovido a catedrático de Direito Romano, tomando posse no cargo a 22 dos mesmos mês e ano. Pouco tempo, porém, exerceu essa cátedra, nomeado que foi, por decreto de 21 de março de 1891, catedrático de Direito das Gentes. ${ }^{15}$

Nos trinta e cinco anos, que vão de 1854 a 1889, de ensino de Direito Romano, durante o Império, na Faculdade de São Paulo, várias vezes professores substitutos assumiram temporariamente a cátedra de Direito Romano. Na maioria dos casos, o impedimento dos catedráticos se deu pelo exercício de funções políticas. Aludindo a esse problema, Duarte de Azevedo, na Memória Histórica de 1864, escreveu:

"Tratam, porém, os legisladores de considerar e de enguer o magistério à altura do seu incontestável merecimento, e da benéfica influência, que lhe cumpre exercer na sociedade, tornem-no independente, com remunerações, que não desdigam do posto eminente, que ocupam aqueles servidores do Estado, e que os ponham ao abrigo da penúria de meios, para a decente

14. Ob. cit., v. 2, p.224

15. Dados biográficos em Sacramento Blake, ob. cit., 1883, v. 1, p. 71-72; e Spencer Vampré, ob. cit., v. 2, p. 299-301. 
mantença de suas famílias; facultem ao Governo a jubilaçāo, com o ordenado proporcional, daqueles que, em oito, ou dez anos, se não mostrarem capazes de ensino, e reservem a aposentadoria, com todos os vencimentos, para os que consumirem vinte e cinco, ou trinta anos, no professorado, ou nele se inabilitarem para outro qualquer serviço; desperte assim a lei, e por outras medidas que tais, tão usadas na Europa, as verdadeiras vocaçōes, arredando dos concursos, pela severidade das provas, as aspirações ilegítimas, $e$ aniquilando, no ânimo dos que se destinam à vida pesada do magistério, a fraqueza, se não desejo natural, de melhorarem sua condição; proceda assim, e não faltará, sob a regra das incompatibilidades, ou independente delas, quem se dedique de alma e coração ao professorado, e exiba abundantemente o fruto de suas locubrações e fadigas, com proveito da mocidade e do país. A política ficaria então de parte; $e$ até a advocacia judicial, que tanto distrai o lente de seus estudos cotidianos, e das leituras de sua cadeira, muita vez de matéria estranha ao serviço de advogado, não se reputaria mais ocupação própria, e digna de um professor de Direito, que, somente no melhor desempenho do seu honroso cargo, deverá concentrar todas as vantagens e glórias do seu presente e do seu futuro". 16

Lecionaram Direito Romano, nesse período, intermitentemente, os professores substitutos Manoel Antônio Duarte de Azevedo, Carlos Leôncio Carvalho, João Teodoro Xavier de Matos, João Jacinto Gonçalves de Andrade (Cônego Andrade), José Maria Correia de Sá e Benevides, José Joaquim Almeida Reis e Francisco Antônio Dutra Rodrigues. Desses substitutos, como já se viu, dois ascenderam à cátedra de Direito Romano: Duarte de Azevedo e Dutra Rodrigues. 


\section{OS COMPÊNDIOS EMPREGADOS NO ENSINO DO DIREITO ROMANO.}

Em Coimbra, antes da Reforma Pombalina, não se adotava no ensino das instituições de Direito Romano um compêndio que o professor, nas aulas, devesse desenvolver com suas explicações. Por isso mesmo, Verney criticava a forma pela qual as Institutas eram estudadas, com estas palavras ásperas:

"Passemos às Instituições, cujo método infinitamente me desagrada. É coisa digna de riso que, reduzindo Justiniano o Corpo do Direito a poucas palavras nas suas Instituições, para que os estudantes pudessem formar em breve a idéia de todo o Direito, a qual com o tempo fossem ampliando, queiram os Mestres que os estudantes comecem pelo Mânzio, Oinotom, Vinio, e outros autores difusíssimos, os quais não dizem palavra que não confirmem com dez textos; $e$, com tanta enudição, confundem o juizo e impedem a percepção. De que nasce que os estudantes tanto entendem as Instituiçōes como a língua da China; $e$ passam aquele primeiro ano lendo muito, e entendendo pouco; e comumente não acabam o primeiro livro" 17

O método então utilizado, mesmo para o estudo das instituições, era o analítico, cujos inconvenientes foram assim resumidos no Compêndio Histórico do Estado da Universidade de Coimbra no tempo da invasão dos denominados Jesuítas e dos estragos feitos nas ciências e nos professores e diretores que a regiam pelas maquinações e publicaçōes dos novos estatutos por eles fabricados, obra publicada em 1771 pela Junta de Providência Literária que D. José constituíra, em 1770, para examinar as causas da decadência daquela Universidade:

"248. Da mesma sorte não deputaram alguns Professores para lerem publicamente uma, e outra Jurisprudência por compêndios: nem também dispuseram, que só depois de aprendido o compêndio sintético se passasse às Lições Analíticas.

249. Antes muito pelo contrário somente estabeleceram liçōes pelo Método Analítico; e para

17. Verdadeiro Método de Estudar. In: Estudos Médicos, Jurídicos e Teológicos, Lisboa, Sá da Costa, 1952, v. 4, p. 116. 
estes precisamente é que destinaram todas as cadeiras, que instituíram: não fazendo menção alguma das Liçōes Sintéticas, nem quèrendo admiti-las nas Escolas, sem embargo do vantajosíssimo uso, que delas haviam já feito o incomparável Cujácio, e outros jurisconsultos egrégios, que com grande utilidade dos ouvintes haviam imitado o seu louvável exemplo.

251. Deste estabelecimento das Lições Analíticas, $e$ do abuso, que era muito natural, que delas se fizesse, como se fez, resultaram dois inconvenientes tāo graves, como são os seguintes.

252. O primeiro: $o$ de se explicarem anualmente em todas as cadeiras de ambas as Faculdades muito poucos textos, e doutrinas, $e$ ainda estas sem conexão, $e$ dedução, que mais que tudo concorrem para elas bem se perceberem, e se imprimirem melhor na memória. Do que era forçoso seguir-se saírem os estudantes da Universidade sem terem chegado a aprender, e nem ainda a ouvir as principais regras, $e$ primeiros princípios de todas as matérias do direito, como na realidade saíam.

253. O segundo inconveniente das mesmas Lições pelo Método Analítico foi o grande embaraço, $e$ invencivel impedimento que com elas se pôs aos bons progressos dos Estudos Jurídicos. Porque como elas eram formadas sem os necessários, e impreteriveis subsídios da interpretação genuína dos textos, como é manifesto, por faltarem estes totalmente na Escola de Bártolo, que era só a que nelas se seguia (o que também se faz certo com igual evidência pela inteira falta dos ditos subsidios que muito facilmente se pode observar nos Comentários e Postilas, que para as mesmas lições 'se ditavam): de tudo isto provinha também que as sobreditas Lições Analíticas mais serviam para confundir, escurecer, e tornar a Jurisprudência arbitrária; e para controverter, e fazer disputável todo o direito, ainda o mais certo, do que para ilustrá-lo, e comunicar-lhe as luzes, de que ele necessita". 18

18. Verdadeiro Método... ob. cit., p. 261-262. 
Para que se corrigisse esse defeito, já havia aconselhado Verney que os estudantes estudassem as Institutas de Justiniano lendo as breves paráfrases que a elas fizeram Perézio e ainda melhor - Heinécio, deixando de lado todos os demais comentadores que "são impertinentes e confusos, e pouco próprios para principiantes -, dos quais digo o que já disse um homem douto dos comentos do Cardeal Caetano sobre S. Tomás: que, depois que os comentadores explicaram S. Tomás, ninguém o entendeu". ${ }^{19}$ Posteriormente, o referido Compêndio Histórico, recomendando a adoção do método sintético-compendiário, ressaltava a necessidade de o ensino das Institutas se fazer por meio de um compêndio:

"Para que as lições públicas das Escolas possam produzir o maior fruto possivel, não basta que se ordenem pelo método sintético. É necessário que se façam também pelo caminho compendiário; e que o direito se ensine por um compêndio completo, e bem ordenado, o qual não só traga as definições mais claras, e exatas; as divisóes necessárias e os princípios de todas as matérias; mas todas estas matérias se achem nele dispostas pela ordem mais natural, e com uma tal dedução, que entre elas ocupem sempre o primeiro lugar as mais simples, e que näo dependem das outras para poderem bem entender-se; $e$ delas se vá sempre passando, como por degraus, para as mais complicadas, e sublimes, não se chegando nunca a estas sem se terem preparado os ouvintes com a prévia noção de todas as outras, que os podem ilustrar para a boa inteligência delas.

Porque tão-somente por meio destes compêndios se pode adquirir facilmente uma idéia sistemática de todo o direito: das partes, e matérias, de que ele se compōe; $e$ da conexão, e relação, que há entre elas" ${ }^{20}$

Feita a reforma da Universidade de Coimbra com os Estatutos baixados por D. José I em 1772, estabeleceu-se neles que o ensino das instituições de Direito Romano - que era o elementar - se faria pela edição, anotada por Boehmer, das Institutas de Justiniano e da Paráfrase de Teófilo, a

19. Ob. cit., p. 169.

20. Ibid., p. 259. 
qual nesse mesmo ano de 1772 , fora impressa na Imprensa Régia, em Lisboa. ${ }^{21}$ Essa obra foi adotada por causa das notas escritas por Boehmer, como se vê desta passagem do capítulo X ("Das Instituições de Direito Civil Romano, que se hão de ensinar no primeiro ano do curso dos legistas") do título III do Livro II dos mencionados Estatutos, onde se determinou aos professores: "E para este fim usarão das que Bohemero ajuntou, e fez estampar na Edição, que deu do texto da Institula com a Paráfrase de Teófilo; não só por se acharem na dita Edição estas notas já unidas com o texto, e com a Paráfrase; mas também pelo merecimento substancial, e intrínseco delas; por serem formadas depois do grande número de escritos, e de observaçōes, com que os jurisconsultos cujacianos, antigos, e modernos, têm trabalhado para dissipar as trevas do Direito Romano". ${ }^{22}$

Reconheciam, porém, os Estatutos que as notas de Boehmer eram insuficientes, pois "ainda há muitos lugares a que Bohemero faltou com as luzes necessárias". $23 \mathrm{Em}$ razão disso e enquanto não fosse elaborado um compêndio pelo professor dessa cadeira -, determinaram eles que o professor escrevesse breves notas aos lugares das Institutas que demandassem maiores luzes, notas, porém, que não podiam ser ditadas aos alunos, mas fornecidas a eles por escrito em cadernos avulsos de onde as copiassem em suas casas. ${ }^{24}$ Com essa determinação, procurava-se evitar o defeito das antigas apostilas ditadas pelos lentes e que, além dos erros grosseiros a que davam margem, consumiam grande parte do tempo letivo, impossibilitando a explicação das Institutas em sua íntegra.

O Aviso Régio de 26 de setembro de 1786 ordenou que as diversas Faculdades escolhessem um ou mais lentes para a elaboração dos compêndios das disciplinas elementares, e, em virtude disso, a Faculdade de Leis atribuiu

21. Lê-se na página de rosto dessa edição, em dois volumes: "Fl. Justiniani imperatoris Institutionum libri quator, seu legitimae scientiae prima elementa. Justus Henningius Boehmer jurisconsultus recensuit, ex codice optimae notae emendavit, annotationibus illustravit, atque Theophili paraphrasin subjunxit cum duplici indice, Olisipone, ex typographia regia. Anno MDCCLXXII. Cum facultate Regiae Curiae Censoriae"

22. Item 48.

23. Livro II, título III, item 49.

24. Livro II, título III, itens 49 e 50. 
essa incumbência, para a feitura de todos os necessários (inclusive o relativo às instituições de Direito Romano) a Ricardo Raimundo Nogueira. 25

Em 7 de maio de 1805, outro Aviso Régio, com base em Alvará de 16 de janeiro do mesmo ano, mandou que se adotasse como compêndio para o estudo das Instituições de Direito Romano "o das Instituições de Direito Civil de Heineccio, emendadas e reformadas por Jo. Pedro Waldeck"

Daí a razão de ter sido esse o compêndio cuja adoção, no Brasil, foi determinada pelos Estatutos, de 2 de março de 1825, do Visconde da Cachoeira, e que foram mandados observar, nos cursos jurídicos criados em 1827, pela Lei que os instituiu.

Esse compêndio foi o adotado, por pouco tempo, em São Paulo, por João Crispiniano Soares.

Waldeck - como noticia Landsberg ${ }^{26}$ - foi professor em Göttingen, e, em 1788, publicou "uma desfigurada e superficial reelaboração" dos Elementa iuris civilis secundum ordinem institutionem de Heinécio, a qual chegava, em 1806, à quinta edição, e, ainda em 1828, era utilizada em Göttingen como fundamento das lições. Embora tenha sido jurista de segunda categoria, tornou-se conhecido, não só pela fineza em distinguir, mas também, e principalmente, pela refundição dos Elementa de Heinécio a que deu a denominação de Institutiones Iuris Civilis Heineccianae emendatae atque reformatae, obra que, já em 1805, era editada em Coimbra pela imprensa da Universidade. Nessa reelaboração, Waldeck eliminou o método axiomático seguido por Heinécio, o qual assim é caracterizado por Landsberg:

"Este método quer demonstrar ao estudante a conexão e as causas das proposiçōes jurídicas, para ajudar-lhe a adquirir, assim, o conhecimento cientifico: saber é conhecer perfeitamente a causa das coisas. Em primeiro lugar, é dada uma curta descrição do conceito principal, passando-se, depois, à exata definiçäo. Dessa

25. A propósito, vide Paulo Merêa, O Ensino do Direito. In: Jurisconsultos Portugueses do Século XIX, Lisboa, Edição do Conselho Geral da Ordem dos Advogados, 1947, v. 1, p. 157.

26. Geschichte der Deutschen Rechtswissenschaft, dritte Abtheilung, erster Halbband, Noten, Müchen und Leipzig, Druck und Verlag von R. Oldenbourg, 1898, p. 287-288. 
definição se deduzem as regras jurídicas superiores do instituto jurídico em exame como corolários, os denominados axiomas. Dos axiomas isolados ou da ligação deles decorrem, de novo, os princípios jurídicos particulares que afinal, no direito positivo efetivamente dado, devem ser provados por meio de citações das fontes. Tudo isso em curtas proposições, em bom $e$ muito simples latim; às vezes, são acrescentadas como 'escólios' explicações mais largas. Evidentemente porque os axiomas mediadores entre o conceito $e$ as proposiçōes finais têm capital importância, o método todo se chama axiomático".27

Dessa eliminação resultou um compêndio seco e de não fácil compreensão para os alunos, tanto que, em 1845, Manoel Maria da Silva Brushy publicou, também pela Imprensa da Universidade de Coimbra, três volumes, intitulados Anotações a Waldeck, destinados a afastar como diz o autor no prefácio dessa obra o "quanto medo incutem a proverbial aridez do Direito Romano, e o ímprobo trabalho, que se requer para entender o compêndio de Waldeck", sendo que esse segundo ponto "é o que por imediato e experimentado atemorisa mais" 28

Ao contrário do que ocorreu na Universidade de Coimbra, em que o compêndio de Waldeck foi adotado por muitos anos (em 1842, a Imprensa da Universidade publicava sua quarta edição portuguesa), em São Paulo ele só serviu de base para as liçóes de Crispiniano no segundo semestre de 1854 (quando se inaugurou o curso de Direito Romano) e durante o ano de 1855, pois, na Memória Histórica de 1856 redigida por Antônio Joaquim Ribas, este aplaudia o ato de Crispiniano de substituir o compêndio de Direito Romano de Waldeck pelo de Warnkoenig, e acentuava que, para justificar essa substituição, bastariam "os progressos, que tem feito o estudo de direito e das antiguidades

27. Ob. cit., p. 184-185.

28. p. IV. Antonio Luiz de Souza Henriques Secco em seu Manual Histórico de Direito Romano (Coimbra, Imprensa da Universidade, 1848, p. 73), aludindo a essa obra, a qualifica de "preciosa". 
romanas, graças aos esforços de Niebuhr, Hugo, Savigny, e tantos outros espíritos investigadores e perspicazes". ${ }^{29}$

As Institutiones Iuris Romani Privati de L. A. Warnkoenig foram utilizadas como compêndio, em São Paulo, durante o resto do século XIX. No prefácio da quarta edição dessa obra, publicada em Bonn, em 1860, seu autor salienta que elas vieram à luz muito antes do que ele esperava porque seu editor lhe dissera que elas haviam sido muito vendidas no exterior, sendo adotadas como compêndio, mais recentemente, nas academias, entre outros países, no Brasil. ${ }^{30}$ Essas Institutiones, já na sua terceira edição vinda à luz em 1834, haviam colhido os frutos da ciência romanística da Escola Histórica de Savigny. E na quarta edição - que foi a largamente utilizada no Brasil se valeram elas amplamente dos trabalhos mais recentes de Savigny, de Vangerow e de Maynz. Divide-se essa obra em duas partes: na primeira (a Introdução), examinam-se alguns princípios jurídicos fundamentais, dão-se noções do desenvolvimento da história do Direito Romano (inclusive no império do Oriente e entre os povos do Ocidente), e se estudam as fontes de direito; na segunda (as relativas às instituições propriamente ditas), em quatro livros - seguindo a sistemática das Institutas de Gaio e de Justiniano - trata-se das pessoas (de personis), das coisas e da aquisição delas (de rebus et acquisitionibus earum), das obrigações (de obligationibus) e das ações e de outros modos de persecução do direito (de actionibus et aliis iuris persequendi modis). Escritas em latim, foram tais Institutiones traduzidas para o português por Antônio Maria Chaves e Mello, que se graduara em direito na França. Essa tradução veio à luz, em 1863, na cidade do Rio de Janeiro. Seu prefácio informa que para ela serviu de base a quarta edição do original, que, por suas qualidades, merecera ser adotada por João Crispiniano Soares como compêndio a ser seguido em suas lições. ${ }^{31} \mathrm{Em}$ 1882, publicou-se, também no Rio de Janeiro, pelo mesmo editor, uma segunda edição melhorada. Essas duas edições, tendo em vista o restrito público estudantil, demonstram que o estudo do Direito Romano na Faculdade de São Paulo se

29. Apud Spencer Vampré, ob. cit., v. 1, p. 300.

30. p. III.

31. Instituições de Direito Romano Privado compostas em latim por L. A. Warnkoenig, Dr. in utroque Jure, etc., trasladadas para o idioma vernáculo por Antonio Maria Chaves e Mello (Rio de Janeiro, B. L. Garnier, 1863 -data do prefácio -, p. 1). 
fazia, por parte dos alunos, principalmente por meio delas. Embora o ensino do latim desse como frutos alguns bons latinistas e os Estatutos, que o Decreto 1.386 , de 28 de abril de 1854, mandou observar, mantivessem o exame da língua latina para o ingresso na Faculdade de Direito, muitos estudantes havia, por certo, malpreparados nessa disciplina. Um episódio relatado por Almeida Nogueira é bastante significativo. Referindo-se a um dos alunos da turma acadêmica de 1856 a 1860 Joaquim José Pereira de Santiago - diz ele:

"Era muito estudioso; lutava, porém, com as dificuldades resultantes da deficiência dos seus estudos preparatórios. Por exemplo: quasi nada sabia de latim.

Imaginem como poderia estudar Direito Romano ...

Uma feita, na aula do Crispiniano, o Santiago teve que suar para traduzir um fragmento do Digesto. $O$ rígido mestre, percebendo o embaraço do aluno, mandou que ele tomasse as partes, e perguntou-lhe sucessivamente pelo sujeito, verbo e atributo" 32

Por isso mesmo, aliás, em 1882, Dutra Rodrigues, explicando os §§ 268 e 269 do compêndio de Warnkoenig, alertava quanto à frase "divini iuris sunt res sacrae, religiosae et quodammodo sanctae" que abria o segundo desses parágrafos:

"O tradutor do Compêndio traduziu mal o original, dizendo que as coisas de Direito Divino se dividiam em coisas sagradas, religiosas, $e$, de certo modo, santas, porque o pensamento de Warnkoenig é diferente, não querendo ele dizer que são de Direito Divino as coisas de certo modo santas, mas que as coisas santas, de certo modo, são de Direito Divino" 33

\section{O MÉTODO DE ENSINO.}

A lei de 11 de agosto de 1827, que criou os Cursos de Ciências Jurídicas e Sociais em São Paulo e em Olinda, ao estabelecer em seu artigo 10

32. Ob. cit., 1908, v. 3, p. 255.

33. Direito Romano Resumo completo das preleções desta matéria (taquigrafadas na Faculdade de Direito de São Paulo em 1882 por um Bacharel), São Paulo, Louzada \& Irmão, 1888, p. 228. 
que "os Estatutos do Visconde da Cachoeira ficarão regulando por ora naquilo que forem aplicáveis; e não se opuserem à presente Lei", impôs, para o ensino desses cursos, o método sintético-compendiário que fora instituído em Portugal com a Reforma Pombalina feita pelos Estatutos da Universidade de Coimbra editados em 1772 .

Esse método, adotado em substituição ao analítico, até então usado em Coimbra, era o utilizado principalmente nas universidades alemãs. Baseavase ele na idéia de que a função precípua dos cursos jurídicos era a de ensinar aos estudantes os princípios e o sistema do direito. Por ser dedutivo, o método sintético-compendiário, como salienta Paulo Merêa, ${ }^{34}$ "consistia - segundo a própria linguagem dos Estatutos em dar primeiro que tudo as definições $e$ divisões das matérias, passando-se logo aos primeiros princípios e preceitos gerais mais simples, dos quais se procederia para as conclusões mais particulares $e$ complicadas", e, para isso, "o direito devia ser ensinado por compêndios breves, claros $e$ bem ordenados, nos quais apenas se contivesse a substância das doutrinas, as regras e exceçōes principais e de maior uso, fazendo avultar os princípios na sua conexâo e dando predomínio à didática sobre a polêmica". Por outro lado, para que os estudantes pudessem aprender os princípios e o sistema do direito, era indispensável que o professor ensinasse, durante o ano letivo, toda a matéria contida nos compêndios, devendo as Escolas decidir, se não fosse possível prelecioná-la integralmente, sobre quais as partes menos importantes que poderiam ser suprimidas. Ademais, com a adoção de compêndios se procurava acabar com a prática das apostilas que eram ditadas aos alunos pelos lentes, dando margem a grande perda de tempo letivo e aos erros grosseiros das anotações por ditado.

No ano em que foi instalada a cadeira de Institutos de Direito Romano 1854 - o Decreto 1.386, de 28 de abril, deu novos Estatutos aos cursos jurídicos. Em seu artigo 21, § 3ํㅡㄹ determinou que as Congregações organizassem, no prazo de dois meses a partir da publicação deles, o regulamento complementar para a sua boa execução. Esse regulamento foi aprovado pelo Decreto 1.568 , de 24 de fevereiro de 1855. Nele, mantinha-se o ensino com base em compêndios, como se vê em seus artigos 239 e 240 : 
"Art. 239. As preleções dos Lentes serão dadas sobre compêndios certos e determinados, compostos pelos mesnios Lentes ou adotados dentre os que já correm impressos; precedendo em todo o caso aprovação da Congregação, a qual poderá dar preferência a outros, se assim o entender conveniente ao aproveitamento dos alunos.

A escolha dos compêndios será comunicada ao Governo, e dependerá de sua aprovação definitiva.

Art. 240. Nas preleções darão os Lentes todas as explicações que forem necessárias aos alunos, tanto para mais fácil compreensão da matéria de que tratarem, como para o seu desenvolvimento, para a correção de qualquer doutrina errônea, ou menos conforme aos progressos da ciência, e para o conhecimento dos diferentes sistemas que possam haver sobre o assunto"

No artigo 244, $2^{\underline{a}}$ e $3^{\underline{a}}$ partes, acrescentava, porém, que "cada Lente Catedrático apresentará à Congregação, no $1^{o}$ dia útil do mês de março, para ser por ela aprovado o programa do ensino de sua Cadeira" e que "este programa, depois de adotado, com modificações ou sem elas, nāo poderá ser alterado senão por deliberação da Congregação".

O método sintético-compendiário foi seguido pelos professores da Faculdade de Direito de São Paulo durante todo o período do Império. Nela não ocorreu, com a conseqüência da abolição da obrigatoriedade do compêndio, a mudança, verificada na Faculdade do Recife, de que dá notícia a memória histórica escrita pelo romanista, então professor substituto, Joaquim de Albuquerque Barros Guimarães, em 1882. Nessa memória, ${ }^{35}$ a págs. 10 (na parte concernente ao "desenvolvimento das matérias do curso"), se lê que, em sessão de 6 de dezembro de 1881, a Congregação, para remediar o fato de os compêndios estarem atrasados em face dos avanços da ciência quanto às doutrinas e ao método, adotou a indicação feita por alguns lentes para que os professores catedráticos apresentassem, na primeira sessão dela, em 1882, "programas de ensino por lições ordenadas sistematicamente sobre todas as matérias de cada uma

35. Na Biblioteca Nacional do Rio de Janeiro, há um exemplar dessa Memória Historica (indicação do catálogo: IV, 322, 6, 10). 
das cadeiras", e isso para libertar o professor da obrigação "de seguir os textos de velhos compêndios" e para compeli-lo a acompanhar o progresso científico, dando às matérias do curso um desenvolvimento mclhor. Assim, Recife substituía o compêndio pelo programa. Já em São Paulo, apesar de se elaborarem também programas, manteve-se o método compendiário, com a substituição, feita por Crispiniano em 1856, em vista do progresso da romanística moderna, do compêndio de Waldeck pelo de Warnkoenig. Note-se que, na edição das Institutas de Justiniano que Ernesto Ferreira França - que viria a ser catedrático de Direito Natural na Faculdade de São Paulo - publicou, em 1858, em Leipzig, incluiu ele, na parte final desse livro, ${ }^{36}$ os Iuris Civilis Romani scholarum in usum lineamenta, que nada mais eram do que um programa de estudos dividido em livros, capítulos e parágrafos, e que abarcava a Encyclopaedia et methodologia iuris (Lib. I), a historia fontium iuris romani (Lib. II), o ius actionum et processus civilis (Lib. III) e as Institutiones iuris civilis romani (Lib. $I V$ ). Essa orientação, porém, não encontrou eco na Congregação das Arcadas do Largo de São Francisco.

Os dois objetivos a que visava precipuamente o método sintéticocompendiário - dar uma visão geral dos princípios e do sistema de Direito Romano e acabar com a prática das apostilas - não foram alcançados no ensino desse Direito, durante o Império, na Faculdade de Direito de São Paulo.

Pelas poucas apostilas - editadas, ou não, em forma de livro - que chegaram até nós atinentes a esse período (1854 a 1889), pode-se ter uma idéia de como funcionava, na prática, o método sintético-compendiário no tocante ao Direito Romano.

A mais antiga dessas apostilas que encontrei foi a das lições ministradas por José Maria Correia de Sá e Benevides, como professor substituto, de abril a 25 de setembro de 1877 (já em 31 de julho desse mesmo ano havia passado a catedrático de Direito Natural, Público e das Gentes, em virtude da jubilação, nesse cargo, de Ernesto Ferreira França). Delas há um exemplar na Biblioteca da Faculdade de Direito de São Paulo, ${ }^{37}$ o qual the foi

36. Institutionum D. IUSTINLANI libri $I V$ in usum Academiarum Brasileinsium edidit E. Ferreira França I.U.D., apud F. A. Brockhausium, Lipsiae, MDCCCLVIII, p. 317-329.

37. A indicação do catálogo é: 08-20-4. 
doado, em 22 de janciro de 1923, pelo Prof. João Brás de Oliveira Arruda, que ingressou nas Arcadas em 1877, tendo, portanto, assistido a essas aulas. Tais apostilas se celcbrizaram graças a Rui Barbosa. Este, como deputado, publicou, em apêndice ao parecer sobre a reforma do ensino superior apresentado à Câmara em 13 de abril de 1882, o texto da 39a lição de Direito Romano dada por Sá e Benevides que se encontrava nessas apostilas. A aula toda versara a explicação do $§ 19$ do compêndio de Warnkoenig, do qual o conteúdo assim era exposto pelo referido professor:

"No § 19 o nosso Comp. afirma perante a filosofia do direito que a justiça é uma idéia inata; e na parte final do $§$ estabelece a diferença entre o direito natural $e$ $o$ direito positivo, dizendo que o direito civil, na linguagem moderna, é chamado direito positivo em antítese ao direito natural", 38

Em nota, Rui Barbosa fez-lhe esta crítica contundente:

"A lição de direito romano (!), que aqui se transcreve, é o corpo de delito da falta de seriedade que lavra em grande escala no ensino superior, entre nós. Nāo qualificamos a filosofía, a ciência e a crítica de que esse documento é revelação. O fim da publicidade que ora se lhe dá, é expor ao país a incrivel amostra de um ensino, em que se trata de tudo menos de assunto que corre ao lente o dever de professar. Uma lição do direito romano, em que ao Direito Romano nem remotamente se alude! Este método de ensinar as Pandectas, endeusando o Syllabus, e caricaturando a ciência moderna, devia vir a lume, para que os bons espíritos toquem a chaga que denunciamos, e contra a qual propomos severas medidas. Fazemos justiça aos lentes de mérito, que as nossas Academias contêm; mas o ensino em geral tem descido de um modo incalculável. Parece impossível baixar mais.

Costumam os estudantes de $S$. Paulo reproduzir pela litografía as lições professadas ali. É de uma dessas

38. Obras Completas de Rui Barbosa: Reforma do Ensino Secundário e Superior, Rio de Janeiro, Ministério da Educação e Saúde, 1942, v. 9, t. 1, p. 307. 
litografias que transladanos na integra essa inimitável lição de direito romano.

Note-se que ela é a trigésima nona do curso, e que alude a outras nas quais o professor se ocupou tanto das Institutas, do Digesto e do Código, quanto nesta" 39

Em artigo publicado no Correio Paulistano (São Paulo) e no Jomal do Comércio (Rio de Janeiro), ${ }^{40}$ Sá e Benevides replicou ao ataque de Rui Barbosa, salientando, inicialmente, que a matéria versada na aula em questão era o $\S 19$ do compêndio adotado pela Faculdade, o qual tratava de assunto puramente filosófico (a definição filosófica do Direito Natural e a afirmação de que o Direito Positivo emana da autoridade pública), razão por que a aula teve por objeto matéria própria à disciplina ensinada. Nesse artigo a que Rui treplicou em discurso proferido em sessão da Câmara dos Deputados, a 20 de outubro de $1882^{41}$-, há algumas informações sobre a forma por que, em 1877, se lecionava a cadeira de Direito Romano em São Paulo. Ei-las:-

"É verdade que os meus discípulos tinham autorização minha para tomar notas e reproduzir pela litografia as lições professadas para uso exclusivo deles, sem que eu me responsabilizasse pela reprodução litográfica pois que não me obrigava a rever as notas tomadas antes de litografadas.

Não tenho o hábito como lente de fazer liçōes escritas para reproduzi-las na preleção oral. Costumo falar livremente, dando ao pensamento a forma do momento em que falo e segundo a ordem das idéias, conforme o plano oral da lição, sobre o qual medito, $e$ estudo antes. Assim, pois, não tenho meio de verificar se a preleção oral foi reproduzida com inteira exatidão confrontando-a com o original.

Recorrendo, porém, aos apontamentos que tenho dessa preleção, posso com segurança dizer qual a minha responsabilidade na referida lição impressa",42

39. Ob. cit., v. 9 , t. 1 , p. 307

40. Ele está reproduzido nas Obras Completas... ob. cit., 1948, v. 9, t. 2, p. 285-320.

41. O resumo desse discurso se encontra nas Obras Completas... ob. cit., v. 9, t. 2, p. 127-136.

42. Ibid., v. 9, t. 2 , p. 286. 
e um pouco mais abaixo:

"O compêndio a que se refere a liçāo é Warnkoenig: Institutiones Juris Romani Privati Introductio, cap. $1^{\circ}$, tit. $3^{\circ}, \S 19^{\prime \prime}$.

Nos $\S \S 14,15,16,17$ e 18, o compêndio trata do Direito Natural, das Gentes e Civil, segundo o Direito Romano, e já tinham sido explicados. No § 19, o que cumpria examinar era a noção filosófica do Direito Natural quanto a ser inato à razão, visto como o Direito Positivo Geral e o Direito Romano já tinham sido considerados.

A lição 39ă, que a Comissão se dignou imprimir, versou portanto sobre a matéria própria e não sobre matéria estranha. A lição versou sobre a indagaçẫo do ser a justiça idéia inata" ${ }^{43}$

Ao contrário do que ocorria com os antigos mestres da Universidade de Coimbra - "a palavra lente (e a observação é de Carlos Maximiliano) recorda as preleçōes dos antigos professores de Coimbra, escritas uma vez, retocadas de ano em ano e soporativamente lidas em aula ${ }^{\prime 44}$ Sá e Benevides não lia as lições que houvesse escrito, mas fazia preleções orais seguindo apontamentos tomados quando da preparação da aula, aula essa cuja duração não mais era de hora e meia como determinavam os Estatutos do Visconde da Cachoeira, para que se empregasse meia hora para ouvir os estudantes e a hora restante para a explicação do compêndio, mas, sim, de uma hora, em conformidade com o artigo 69 dos Estatutos para as Faculdades de Direito mandados observar pelo Decreto 1.386, de 28 de abril de 1854, e no qual se preceituava: "Os Lentes sāo obrigados a lecionar em todos os dias úteis da semana, por espaço de uma hora, podendo, sempre que o julgarem conveniente, ouvir alguns dos alunos sobre a lição da véspera". Portanto, com essa redução, a hora de aula era geralmente toda empregada no desenvolvimento da parte do compêndio tomada para servir-lhe de objeto. Utilizava-se Sá e Benevides do original em latim das Institutiones Juris

43. Obras Completas... ob. cit., v. 9, t. 2, p. 287.

44. Apud Cândido de Oliveira Filho, Métodos de Ensino das Ciências Jurídicas. In: Livro do Centenário dos Cursos Jurídicos (1827-1927), Rio de Janeiro, Imprensa Nacional, 1929, v. 2, p. 441. 
Romani Privati de Warnkoenig, e não da tradução já exisıente. Apesar da adoção do compêndio, persistia o velho hábito da elaboração, certamente por parte de algum dos estudantes, de apostilas resultantes de anotações tomadas em aula e reproduzidas, sem a revisão do professor, litograficamente. Esse hábito se explicava até pelo fato de que as preleções desenvolviam a matéria contida no compêndio, não se limitando, portanto, o professor a simples esclarecimentos sobre pontos obscuros, e este, muitas vezes, divergia da opinião de Warnkoenig, emitindo a sua, apoiada, ou não, em outros autores que citava. Essas características do método adotado ressaltam nítidas da apostila das lições de Sá e Benevides professadas em 1877. Mas vinham de longe. Do ensino de Crispiniano a tradição guardou estes traços, de que dá notícia Vampré, e que mostram, à falta hoje do registro gráfico de suas preleções, que ele se fazia por explanações orais eloqüentes, sem guardar fidelidade à doutrina do compêndio seguido:

"Professava as doutrinas da escola histórica, seguindo a Savigny, seu autor predileto.

Começando baixinho as preleções, entusiasmava-se gradualmente, ao ponto de apostrofar, em voz ostentórica, os autores que combatia.

Chegando-lhe aos ouvidos que o dr. Furtado, que lecionava, à mesma hora, na aula contígua, se queixava de rumor de suas vozes, disse Crispiniano sempre orgulhoso:

'Eu ergo a voz, porque tenho confiança no que digo. Não receio errar; não temo que o mundo inteiro me ouça'.

De outras vezes, não hesitava em dizer: 'Indubitavelmente Papiniano errou...' ou ainda: 'Donellus, Cujacius, e a corrente dos comentadores, sāo desta opiniäo: eu, porém, entendo que eles erraram, $e$ penso diversamente...'

$A$ um estudante, que opunha, aos ensinamentos da cátedra, a doutrina geral dos clássicos do Direito Romano, replicou:

' - Então o sr. não admite que um jurisconsulto moderno corrija um jurisconsulto antigo?" 45

45. Ob. cit., v. 1, p. 182. 
Aliás, mcsmo com relação a professor que seguia em suas aulas o compêndio que ele próprio havia escrito, faziam-se apostilas, por causa do desenvolvimento dado nas preleções aos parágrafos do livro. Na segunda edição, datada de 1872, das Apostilhas de Prática, referentes às lições de Hermenêtica Jurídica e do Processo Civil dadas por Joaquim Ignácio Ramalho, colega e contemporânco de Crispiniano, que adotava para o processo civil o compêndio que publicara em 1861 (Prática Civil e Comercial), ${ }^{46}$ encontra-se esta nota final bastante elucidativa sobre a elaboração e a difusão das apostilas:

"Um acidente lastimável (o desastre em 6 de setembro de 1865 na inauguração da estrada de ferro de S. Paulo) impediu que o ilustrado professor terminasse as suas preleções, das quais coligimos para nosso uso, $e$ de alguns colegas, estas lições, de apontamentos tomados no correr da exposição. Conhecemos que muitas vezes tiramos à frase precisa e elegante do sábio mestre a sua força, porém, apenas procurávamos apanhar o pensamento, e a nós e não a ele se devem atribuir os erros que porventura se encontram: pois, como fica dito, redigíamos sobre apontamentos $e$ muitas vezes com o único auxílio da memória.

Destas Lições se iam publicando diariamente, à tarde, no ano de 1865, as que eram pela manhã explicadas na Faculdade, pelo que foi muito imperfeito o trabalho; e tomados raríssimos os poucos exemplares que se imprimiram, anuímos aos constantes pedidos de uma nova edição, mais pelo desejo de satisfazê-los, do que levado por qualquer outro motivo. Procuramos nesta segunda edição sanar as incorreções da primeira, e adicionamos-lhes algumas notas no sentido de melhor inteligência do texto, feitas porém sempre ao correr da pena e à medida que se iam publicando. Possa isto servir de desculpa para as imperfeições de que estão cheias" 47 Marques.

46. Foi impressa em São Paulo pela Tipografia Imparcial de Joaquim Roberto de Azevedo

47. Essas apostilas de Processo Civil foram impressas na Tipografia Americana, em São Paulo, em 1872; a nota transcrita no texto, que se encontra a p. 309 , informa que elas dizem respeito âs aulas dadas por Joaquim Ignácio Ramalho, em 1865. 
Pela apostila das aulas de Sá e Benevides, verifica-se, ainda, que um dos objetivos da adoção do método sintético-compendiário o de se dar ao aluno uma visão geral de toda a matéria contida no compêndio - não era normalmente alcançado. Perdia-se muito tempo com longas explanações sobre os princípios gerais contidos na introdução do compêndio de Warnkoenig, que se encontravam no capítulo primeiro dela (Generaliter de iuris origine atque progressu), dividido em cinco títulos, assim dispostos: I. De iure et iustitia; II. De iuris origine atque progressu; III. De iure naturali, gentium et civili; $I V$. De iurisprudentia; $V$. De publico et privato iure, sive totius iurisprudentiae in partes suas distributio. Com efeito, para explicar os cinco primeiros parágrafos em que se dividia o título I relativo aos conceitos de direito e de justiça, Sá e Benevides deles se ocupou, em 1877, em dezoito aulas, das 74 que, de abril a 25 de setembro, proferiu nesse ano letivo. Por isso, na trigésima nona lição a criticada por Rui Barbosa por versar exclusivamente direito moderno ainda estava na explicação do § 19 do compêndio de Warnkoenig, o qual integra o título III (De iure naturali, gentium et civili) da Introdução, e se encontra na pág. 6 desse livro, constituído de 354 páginas de texto. Nesse passo, evidentemente, seria impossível sequer explicar o livro I das Institutiones Iuris Romani Privati concernente ao direito das pessoas (De personis). Por outro lado, persistia-se numa das falhas do antigo método analítico adotado na Universidade de Coimbra antes da Reforma Pombalina, falha essa exprobada por Verney, em texto anteriormente transcrito, no qual dizia ele que, enquanto Justiniano reduzira o corpo do direito a poucas palavras em suas Institutas, "para que os estudantes pudessem formar em breve a idéia de todo o direito, a qual com o tempo fossem ampliando", os mestres conimbricenses, pela prolixidade dos comentários que faziam e dos autores de que se utilizavam, "comumente não acabam o primeiro livro". Esse defeito não era peculiar a Sá e Benevides, que era muito voltado à filosofia do direito, mas se encontra também em Dutra Rodrigues, cujas preleções - e elas espelham o seu ensino, pois ele, como informa Vampré, ${ }^{48}$ além de falar torrencialmente, "repetia, em cada ano, quase literalmente, o que expusera nos anteriores" - foram resumidas e publicadas, em 1887, por um estudante, em livro do qual o prefácio mostra que o método empregado por esse professor era substancialmente o mesmo: 


\section{Ao Leitor}

Resumindo em uim volume as excelentes preleçōes de Direito Romano, expendidas em aula, na Faculdade de Direito, pelo ilustre jurisconsulto e lente daquela Faculdade Dr. Dutra Rodrigues, acreditamos auxiliar muito aos Srs. estudantes de Direito; pois que, como sabemos, o Direito Romano é a fonte de todos os mais direitos, e muitas vezes temos necessidade de recorrer a ele, para consultar ou salvar alguma ou algumas questões de que não tenha cogitado o legislador.

Cumpre, porém, advertir ao leitor, de que estas preleções foram dadas à publicidade sem a revisão $e$ responsabilidade de seu ilustre autor, polulando, por conseqüência alguns erros e faltas em várias liçōes, pelo que esperamos que a benevolência $e$ inteligência do leitor facilmente desculpará.

Para a melhor compreensão desta obra é necessário que o leitor tenha o Compêndio de Direito Romano de Warnkoenig, cujos parágrafos e capítulos são nestas preleções brilhantemente desenvolvidos.

Achamos imprescindivel necessidade publicar, sob o título Introdução, a história resumida do Direito, desde a criação do mundo até os nossos tempos, extraída dos melhores escritores.

Rio de Janeiro, $1^{\circ}$ de janeiro de 1887" 49

Nessa obra, que abarca, em suas 250 páginas, 38 preleçôes, estas só esgotam a matéria que era tratada nos cinco títulos em que se dividia o capítulo I

49. Preleções de Direito Romano expedidas em aula pelo Dr. Francisco Antônio Dutra Rodrigues (Lente catedrático da Faculdade de S. Paulo) com uma introdução sobre a história geral do Direito, exaraída dos melhores escritores de Direito por um estudante de Direito, Rio de Janeiro, Imprensa Industrial, 1887, v. 1, p. 1.

Em 1888, impresso em São Paulo, na Tipografia Louzada \& Irmāo, vinha à luz Direito Romano - Resumo completo das prelęóes desta matéria (taquigrafadas na Faculdade de Direito de S. Paulo, em 1882) por um Bacharel em Direito, em cujo prefácio (p. 1) se diz que esse trabalho nada mais é do que um resumo das preleçōes, feitas em 1882, pelo referido professor. 
da Introdução do compêndio de Warnkoenig, além de fornecer um resumo da história do Direito Romano, a descrição do Corpus luris Civilis e noções de direito escrito (ius scriptum) como fonte do direito objetivo, matérias essas que são versadas nas 33 primeiras páginas do compêndio referido.

Pelágio Lôbo, porém, dá notícia de que o ensino de Dircito Romano sob a direção de Duarte de Azevedo abarcava toda a matéria no que fosse essencial e básico. Diz ele:

"Tive à mão essas preleções nas apostilas pertencentes a meu pai, da turma de primeiranistas de 1880, apanhadas taquigraficamente e copiadas pelo estudante Antônio Mercado - com a mesma letra igual, firme e clara que conservou até ofim dos seus honrados 80 anos - volume esse que doei à biblioteca da Academia, ao tempo em que era diretor Alcântara Machado. As preleçōes abraçam o curso completo noções preliminares de Direito, justiça, 'aequitas', pessoas, coisas, obrigaçōes, e chegam à família $e$ sucessões, calcadas na orientação adotada pelo sólido Mackeldey, edição belga". 50

Como quer que seja, na cadeira de Institutas do Direito Romano, punha-se o estudante em contato com o Direito Romano, dando-lhe noções básicas necessárias ao seu estudo. Seus princípios sobre Direito das Coisas, Direito das Obrigações, Direito de Família e Direito de Sucessões eram aflorados pelos professores de Direito Civil, dada a necessidade, inclusive, de muitas vezes se ter de recorrer ao Direito Romano para suprir as lacunas do Direito Civil brasileiro que continuava a ser, basicamente, o contido nas Ordenações Filipinas de 1603, com as alterações posteriormente introduzidas. Freqüentíssimas, por isso mesmo, eram as remissões ao Direito Romano feitas pelos compêndios utilizados no estudo acadêmico do Direito Civil, como, a princípio, as Instituições de Melo Freire, e, mais tarde, o Curso de Direito Civil Brasileiro de Antônio Joaquim Ribas. Eminentemente romanista, aliás, era a formação dos professores que, no Império, lecionaram essa cadeira. Justino de

50. Ob. cit., p. 270. A apostila a que alude Pelágio Lôbo infelizmente não mais se encontra na biblioteca da Faculdade de Direito de São Paulo, não se achando sequer sua indicaçāo no fichário de obras ou de autores. 
Andrade, que a ensinou de 1868 a 1890 , era versado nas obras de Savigny, de Puchta, de Windscheid. ${ }^{51}$ Do profundo conhecimento do Direito Romano de Antônio Joaquim Ribas dá pujante demonstração a obra que deixou escrita, especialmente scu livro clássico sobre Direito Civil. ${ }^{52}$ Vicente Mamede, exigia (segundo o depoimento de Waldemar Ferreira, que foi seu aluno) que os estudantes, quando argüidos, soubessem de cor capítulos não apenas da obra de civilistas como Ribas, Lafaiete, Coelho da Rocha, Aubry et Rau, mas também de romanistas como Maynz, Mackeldey, Bonjean, Van Wetter, Ortolan; por isso, ficou na tradição que, além de fazer questão fechada da assiduidade dos alunos, lhes marcava a lição de cada dia, com a indicação do livro e da página de cada autor, dizendo: " - Este ponto deve ser estudado em Maynz, do § tal ao § tal; no Conselheiro (Conselheiro Ribas), da página tal a tal; no Conselheiro Lafaiete, da página tal a lal $^{\prime \prime} .53 \mathrm{E}$ também professores de outras matérias freqüentemente recorriam, em seu ensino, ao Direito Romano. De Ernesto Ferreira França, que se doutorou em Direito Civil e em Direito Canônico pela Faculdade de Direito de Leipzig, diz Almeida Nogueira que "era principalmente, ou talvez exclusivamente - romanista. Sentia-se deslocado na cátedra de Direito Comercial e achava meios de, na regência dela, explicar digressivamente - Direito Romano".54

Uma última informação digna de nota, sobre o método de ensino, nos fornece a apostila de Sá e Benevides em 1887. Na 26ª lição, em 5 de junho, começou ele acentuando que "na forma dos estatutos os Senhores têm de fazer duas dissertações: dou quanto ao primeiro - análise do $\$ 3^{o}$ desse comp.: introdução, cap. I $^{o}$ Tit. I $^{\circ}$ ". Era o cumprimento do disposto no artigo 243 do Regulamento Complementar dos Estatutos das Faculdades de Direito aprovado pelo Decreto 1.568 , de 24 de fevereiro de 1855 , para a execução do $\S 3^{2}$ do artigo 21 do Decreto 1.386, de 28 de abril de 1854. Nele se lia: "O Lente de cada cadeira dará anualmente aos seus discípulos dois pontos escolhidos, dentre as mais importantes doutrinas que lhes houver explicado, para dissertações por escrito

51. Spencer Vampré, ob. cit., v. 2, p. 43.

52. Curso de Direito Civil Brasileiro, Rio de Janeiro, Universal de Laemmert, 1865, vs. 1 e 2 : parte geral.

53. Spencer Vampré, ob. cit., v. 2, p. 296.

54. Ob. cit., v. 1, p. 262. 
em língua vulgar, as quais serāo feitas e entregues no prazo de mês e meio. Estas dissertações, depois de examinadas pelos respectivos Lentes, serão remetidas por eles até o fim do ano letivo ao Secretário, que as arquivará por ordem dos anos". A tanto se reduzira a determinação dos Estatutos do Visconde da Cachoeira de que os professores deveriam dar, no fim de cada mês, um ponto aos estudantes, dentre os explicados, para que fizessem uma dissertação destinada a aferir, a fim de que fossem considerados no final do ano letivo, seu bom gosto no escrever e o progresso nos conhecimentos da disciplina.

\section{O MÉTODO SINTÉTICO-COMPENDIÁRIO E A PRODUÇÃO DE OBRAS DIDÁTICAS PELOS PROFESSORES DE DIREITO ROMANO DA FACULDADE DE SÃO PAULO.}

À semelhança do que ocorreu em Portugal, em que, apesar do empenho das autoridades no sentido de que os professores da Universidade de Coimbra escrevessem os seus compêndios, estes - como observa Teófilo Braga ${ }^{55}$ - "nunca apareceram, salvo um ou outro que naufragou nas Congregaçōes, e os escritos de Paschoal José de Mello", no Brasil, embora desde os Estatutos do Visconde da Cachoeira já fizesse a mesma recomendação, o certo é que, com raras exceções, algumas das quais não foram aprovadas, não se elaboraram os desejados compêndios. De nada adiantou a promessa de prêmios, como a contida no artigo 72 dos Estatutos aprovados pelo Decreto 1.386, de 28 de abril de 1854: "Terão direito a prêmios os Lentes ou quaesquer pessoas que compuserem compêndios ou obras para uso das aulas, e os que melhor traduzirem os publicados em língua estrangeira, depois de terem sido ouvidas sobre eles as Congregaçōes e de serem aprovados pelo Governo". Essa promessa, aliás, voltou a ser feita no artigo 137 dos novos Estatutos às Faculdades de Direito do Império mandados observar pelo Decreto 3.454, de 26 de abril de 1863: "Terāo direito a prêmios os Lentes, ou quaesquer pessoas, que compuserem compêndios, ou obras, para uso das aulas, ou que melhor traduzirem os que forem publicados em língua estrangeira. Esses prêmios porém não poderāo ser conferidos sem que o Governo 706.

55. História da Universidade de Coimbra, Lisboa, Academia Real das Ciências, 1898, t. 3, p. 
aprove os ditos compêndios, ou traduções, tendo ouvido sobre eles as Congregaçōes".

Por falta de compêndios escritos pelos próprios professores - o de Crispiniano, que seria a exceção, em São Paulo, no terreno do Direito Romano, ficou inédito, não tendo sido, portanto, utilizado por seus alunos -, o método sintético-compendiário, então adotado, deu margem àquilo que, com ele, se procurava evitar: a utilização das apostilas. Como o professor desenvolvia suas aulas sobre os parágrafos do compêndio adotado, manifestando-se, por vezes, contra a doutrina neles contida, faziam-se apostilas com base nos apontamentos, em geral imperfeitos, colhidos nas aulas, e era por elas que os alunos estudavam. Reproduzia-se, no Brasil, o que sucedia em Portugal, onde as apostilas se denominavam "sebentas", e contra as quais de nada adiantaram providências como a do edital de 1786 do reformador-reitor Castro que proibia, em Coimbra, que os alunos tomassem notas em aula, sob pena de sanções severas: "E ordeno outrossim aos bedeis que vigiem muito cuidadosamente pela exata observância desta importante providência; e que tenham a maior vigilância em apontar todos aqueles estudantes que por qualquer modo a pretenderem iludir. Os quais pela primeira vez serão multados em $1 \$ 600$ réis para os mesmos bedeis que os apontarem; pela segunda vez pagarão a mesma multa em dobro, que terá a mesma aplicação, e incorrerão além disso na pena de dois meses de prisão e de lhes serem havidas por sem causa as faltas que naquele tempo fizerem nas suas respectivas aulas; e pela terceira vez, finalmente, ficarāo incursos na perda irremediável do ano". 56

Ainda no final do Império - como o demonstram as apostilas já referidas, das aulas de Sá e Benevides, Duarte de Azevedo e Dutra Rodrigues ${ }^{-57}$ persistia o uso delas.

Aliás, durante o Império, o compêndio mais desenvolvido de Direito Romano Privado é a História Interna do Direito Romano Privado até Justiniano, de autoria de Luiz Antônio Vieira da Silva. Essa obra foi a primeira sobre a

56. Braga, ob.cit., t. 3, p. 701.

57. Spencer Vampré diz que "as suas apostilas de Direito Romano, conhecidas pelos nomes de Dutrinha, e Dutrāo, serviram de pábulo a muitas geraçōes de estudantes" Suas preleçōes, como já se salientou no texto, foram publicadas em resumo nas duas obras referidas na nota 45 . (ob. cit., v. 2, p. 224) 
denominada história interna escrita em língua portuguesa, e foi publicada pela Editora Eduardo \& Henrique Laemmert, no Rio de Janeiro, em 1854, ano em que o Direito Romano começou a ser lecionado em nossos cursos jurídicos. Seu autor, natural do Maranhão, embora fosse doutor em leis e em cânones pela Universidade de Heidelberg e se houvesse destacado como historiador e parlamentar, não foi professor de Direito em São Paulo ou em Recife, e talvez, até por isso, seu compêndio que é obra de mérito, e que revela o conhecimento das fontes romanas e da literatura romanística alemã - não foi adotado por qualquer das duas Escolas então existentes.

Os outros dois compêndios de Direito Romano que se publicaram também no Império saíram das penas de dois professores de Recife - Joaquim de Albuquerque Barros Guimarães e José Soriano de Souza. Ambos vieram à luz em 1883. O do primeiro - obra que alcançou uma segunda edição em $1904^{58}$ - se intitula Elementos de Direito Romano, e abarca apenas a parte introdutória do programa seguido na Faculdade de Direito do Recife no ano de 1883, não chegando, portanto, a tratar do direito das pessoas, das coisas e das ações, segundo a classificação adotada pelas Institutas de Gaio e de Justiniano. O do segundo $^{59}$ - que foi impresso com o pseudônimo Vico também observa o referido programa adotado no ano de 1883, e vai até o ponto XXXIX dele. Desde o ano anterior - 1882 - a Faculdade de Direito do Recife, como já se salientou anteriormente, havia adotado o sistema dos programas, libertando, assim, os professores "da obrigação de seguir os textos de velhos compêndios".60

Em Direito Romano, durante o Império, a única obra de professor da Faculdade de São Paulo que, com fins didáticos, veio à luz foi uma edição das Institutas de Justiniano, baseada no texto que se encontra no Corpus Iuris Civilis dos irmãos Kriegel, e publicada por Ernesto Ferreira França, em 1858, em Leipzig, com este título: Institutionum D. Iustiniani Livri $I V$ in usum Academiarum Brasiliensium edidit E. Ferreira França I.U.D.. A raridade dos

58. Elementos de Direito Romano, $2^{\mathrm{a}}$ edição, Pernambuco, Manoel Nogueira de Souza-Editor, 1904 (edição póstuma).

59. Pontos de Direito Romano segundo o programa da Faculdade de Direito em 1883 por Vico, Recife, Central, 1883.

60. Clovis Bevilaqua, História da Faculdade de Direito de Recife, $2^{\text {a }}$ edição, Brasília, Instituto Nacional do Livro e Conselho Federal de Cultura, 1977, p. 162. 
exemplares que restam dela ${ }^{61}$ Spencer Vampré, ${ }^{62}$ na biografia que escreveu desse professor alude a vários trabalhos seus, mas salienta sobre esse, embora ele esteja relacionado no Dicionánio de Sacramento Blake a que o historiador da Faculdade de Direito de São Paulo remete os leitores demonstra que não foi usada em nosso ensino jurídico, embora seu autor, no prefácio escrito em latim, esperasse que esse pequeno livro, destinado precipuamente aos alunos, não fosse inútil aos próprios professores ("Denique speramus fore, ut hicce libellus, quamquam alumnis praecipue destinatus, tamen ne ipsis quidem professoribus prorsus inutilis esse videatur"). ${ }^{63}$

61. Na Biblioteca Nacional, no Rio de Janeiro, há um exemplar, cuja inđicação no catálogo é: III, $3,1,2$.

62. Ob. cit., v. 2, p. 94.

63. Institutionum ... ob. cit., p. VIII. 